\title{
PERAN PEMERINTAH KELURAHAN DALAM PENINGKATAN KESEJAHTERAAN MASYARAKAT DI KELURAHAN MATA ALLO KECAMATAN BAJENG KABUPATEN GOWA
}

\author{
Muh. Arifin ${ }^{1}$, Alimuddin Said ${ }^{1}$, Andi Nuraeni Aksa ${ }^{1}$ \\ Program Studi Ilmu Pemerintahan Fakultas Ilmu Sosial Dan Ilmu Politik \\ Universitas Muhammadiyah Makassar \\ Jl. Sultan Alauddin No. 259 Makassar 90221 Telp. 0411 - 866972 ext. 107 Fax. 0411 - 865588
}

\begin{abstract}
The purpose of this study was to analyze the role of the government in Mataallo sub-district, Bajeng district, Gowa Regency, as well as the factors of social welfare improvement in Mataallo sub-district, Bajeng District, Gowa regency. Type of this research was survey study which was direct to the object of the research descriptively by the informants that had been determined in advance. The data collected primarily and secondarily by data collection techniques as follows: observation, and in-depth interviews to the informants and the last five years secondary data. The data were analyzed descriptive qualitatively. Based on the research results showed that the Government's role in improving public welfare in the Mataallo sub-district, Bajeng District, Gowa regency, from those, it can be concluded that the implementation of the government's role could be seen from the organizers of the event of sub-district government, community empowerment, community services, the implementation of public peace and order, and maintaining public service infrastructure and facilities were not maximum, it was proved by the activities and urban government programs did not run optimally, empowerment and improving the welfare of the people in the Mataallo sub-district, Bajeng district, Gowa regency. Factors affecting the public welfare in the Mataallo sub-district, Bajeng district, Gowa regency included internal factors and external factors. Internal factors were income, education, and employment, while external factor was the ease.
\end{abstract}

Keywords: role of government, public welfare.

\begin{abstract}
ABSTRAK
Tujuan dilaksanakan penelitian ini adalah untuk menganalisis peran Pemerintah Kelurahan Mataallo Kecamatan Bajeng Kabupaten Gowa dan faktor-faktor dalam peningkatan kesejahteraan masyarakat di Keurahan Mataallo Kecamatan Bajeng Kabupaten Gowa. jenis penelitian adalah penelitian survey langsung ke objek penelitian dengan tipe deskriptif dengan informan yang telah di tentukan. Data dalam penelitian ini di kumpul dengan data prime dan sekunder yang menggunakan teknik pengumpulan data berupa ; observasi, dan wawancara secara mendalam terhadap informan dan data sekunder lima tahun terakhir. Data tersebut di analisis secara deskriptif kualitatif. Berdasarkan hasil penelitian mnnjukan bahwa peran Pemerintah kelurahan dalam peningkatan kesejahteraan masyarakat di Kelurahan Mataallo Kecamatan Bajeng Kabupaten Gowa, ternyata dapatlah disimpulkan bahwa pelaksanaan peran pemerintah kelurahan dilihat dari penyelenggara kegiatan pemerintah kelurahan, pemberdayaan masyarakat, pelayanan masyarakat, penyelenggaraan ketentraman dan ketertiban umum, pemeilharaan prasarana dan fasilitas pelayanan umum, belum maksimal, seperti kegiatan dan program pemerintah kelurahan tidak berjalan secara maksimal, belum maksimalnya pemberdayaan masyarakat dan peningkatan kesejahteraan masyarakat di Kelurahan Mataallo Kecamatan Bajeng Kabupaten Gowa. Faktor yang mempengaruhi peningkatan kesejahteraan masyarakat di Kelurahan Mataallo Kecamatan Bajeng Kabupaten Gowa meliputi faktor internal dan faktor eksternal. Faktor internal ; pendapatan, pendidikan, dan pekerjaan, sedangkan faktor eksternal seperti kemudahan.
\end{abstract}

Kata kunci: peran pemerintah, kesejahteraan masyarakat. 


\section{A. PENDAHULUAN}

Undang-Undang Dasar Negara RI tahun 1945 merupakan hukum tertinggi dan instrumen utama bagi pemerintah Indonesia. Selama 60 tahun, UUD 1945 ini telah menuntut proses perubahan berbagai lembaga pemerintahan dan menjadi dasar bagi stabilitas politik, kebebasan hak asasi manusia, pertumbuhan ekonomi dan kemajuan sosial. Secara umum tingkat penerapan desentralisasi suatu negara mendasari cara negara (pemerintah) dalam mendefinisikan perannya dalam rangka mencapai tujuan-tujuannya. Apakah negara harus terlibat dalam berbagai bidang kehidupan masyarakat, ataukah negara hanya melibatkan diri sebatas pada bidang-bidang diluar kemampuan masyarakat? Apakah segala urusan harus dikendalikan pemerintah pusat, atau sejauh mungkin dilaksanakan oleh pemerintah lokal, kecuali hal-hal fundamental yang menyangkut kepentingan umum masyarakat negara? Hal-hal tersebut merupakan persoalan-persoalan yang signifikan.

Penyelenggaraan pemerintahan di indonesia diarahkan untuk menjadi mewujudkan tujuan nasional (National Goal) yakni melindungi segenap bangsa Indonesia, memajukan kesejahteraan umum, mencerdaskan kehidupan bangsa, dan ikut serta melaksanakan ketertiban dunia. Fungsi pemerintahan pada umumnya berupa penyediaan pelayanan umum, pengaturan dan perlindungan masyarakat serta pembangunan dan pengembangan. Sedangkan tugas dan fungsi pemerintah adalah membuat regulasi tentang pelayanan umum, pengembangan sumber daya produktif, melindungi ketentraman dan ketertiban masyarakat, pelestarian nilai-nilai sosio-kultural, kesatuan dan pencapaian keadilan dan pemerataan, pelestarian lingkungan hidup, penerapan dan penegakan peraturan perundangundangan, mendukung pembangunan nasional dan mengembangkan kehidupan berbangsa, bernegara dan bermasyarakat berdasarkan Pancasila serta menjaga tegak, lestari dan utuhnya Negara Republik Indonesia. Dilihat dari fungsi dan tugas pemerintah seperti teridentifikasi di atas, maka dalam mengoptimalkan penyelenggaraannya diperlukan penerapan good governance sebagai suatu tata pemerintahan yang baik yang di dalam pelaksanaannya didukung tiga pilar utama yakni pemerintah, masyarakat, dan swasta. Prinsip tersebut dijabarkan sebagai berikut : akuntabilitas, Transparansi, Rule of law,. Kapabilitas, Responsif.

Pemerintahan Umum adalah suatu sistem yang dikembangkan dalam rangka memeliahara persatuan dan kesatuan seluruh elemen pemerintahan melalui asas dekonsentrasi, desentralisasi, dan tugas pembantuan. Pemerintahan umum bertujuan untuk memelihara keutuhan negara yang apa pada umumnya dilakukan secara seragam melaui standarisasi yang rasional dan didasarkan pada kepentingan negara. Dalam menjalankan peranannya, pemerintah umum dapat memilah-milah kewenangan dan bahkan dapat mendistribusikan kewenangan secara rasional dan hierarkis kepada pemerintahan bawahan melalui suatu sistem dan perangkat birokrasi yang efisiensi. Pada zaman modern ini, sistem pemerintahan umum dihadapkan pada suatu fenomena politik dimana kekuasaan sentral tersebut dituntut untuk dibagikan seleluasa mungkin kepada unit-unit pemerintahan di daerah dengan alasan-alasan efisiensi dan menyesuaikan kebijaksanaan negara pada kebhinekaan pemerintahan di daerah. Peran Pemerintah Daerah dalam pelaksanaan pembangunan daerah merupakan salah satu syarat mutlak dalam era kebebasan dan keterbukaan ini. Pengabaian terhadap faktorfaktor ini, terbukti telah menyebabkan terjadinya deviasi yang cukup signifikan terhadap tujuan pembangunan itu sendiri pembangunan itu sendiri yaitu keseluruhan upaya peningkatan ekonomi dan kesejahteraan masyarakat.

Pembangunan nasional merupakan perwujudan tujuan nasional bangsa Indonesia pada intinya bertujuan untuk mewujudkan masyarakat adil dan makmur yang merata baik materiil maupun spiritual berdasarkan Pancasila dan Undang-undang Dasar 1945. Pembangunan nasional yang dilaksanakan pada hakekatnya mencakup semua aspek kehidupan manusia yang dilakukan secara terarah, terpadu dan berkesinambungan serta 
menyeluruh keseluruh pelosok tanah air. Agar pembangunan nasional sesuai dengan sasaran, maka pelaksanaannya dapat diarahkan kepada daerah untuk mengatur dan mengurus kegiatan pembangunannya sendiri. Pembangunan daerah yang merupakan bagian integral dari pembangunan nasional mencakup seluruh segi kehidupan masyarakat, sudah barang tentu memerlukan pengorganisasian pemerintah yang mampu mengikuti perkembangan zaman. Pelaksanaan pembangunan yang ditujukan demi kemakmuran rakyat tersebut, penyelenggaraannya dilakukan menyeluruh sampai ke pelosok daerah sesuai dengan kondisi daerah masing-masing, dengan kata lain bahwa negara memberikan kesempatan dan keleluasaan kepada daerah untuk menyelenggarakan otonomi. Implementasi kebijakan otonomi daerah tersebut mendorong terjadinya perubahan secara struktural, fungsional dan kultural dalam keseluruhan tatanan penyelenggaraan pemerintahan daerah.

Dalam kerangka sistem Pemerintahan di Indonesia, peran dan fungsi pemerintah Kelurahan merupakan bagian penting dan menentukan, terutama bila dikaitkan dengan kemampuan dalam memberikan pelayanan kepada masyarakat. Kondisi pelayanan masyarakat yang selama ini menjadi permasalahan dan keluhan masyarakat pada kenyataannya belum memenuhi harapan masyarakat. Kedudukan Kantor Lurah sebagai ujung tombak dalam penyelenggaraan pemerintahan Republik Indonesia yang langsung berhadapan dengan masyarakat. Baik buruknya pelayanan masyarakat yang dilaksanakan di Kelurahan merupakan cerminan dari Pemerintah. Oleh karena itu Pemerintah Kelurahan harus benarbenar menampilkan sosok sebagai instansi Pemerintah yang mampu memberikan pelayanan yang memuaskan kepada masyarakat, dengan kualitas pelayanan yang baik, sehingga mampu menampilkan citra positif dari Pemerintah secara keseluruhan.

Kesejahteraan masyarakat adalah tujuan mengapa negara ini terbentuk. Kesejahteraan masyarakat akan berimbas pada politik, hukum, ekonomi, dan sebagainya. Kesejahteraan masyarakat bisa diartikan sebagai pilar utama dalam bangunan yang bernama negara. Tanpa kesejahteraan masyarakat sebuah negara akan jalan di tempat. Jika merujuk teori motivasi Maslow. Rumah adalah kebutuhan utama yang harus terpenuhi sebelum menginjak tangga selanjutnya. Memiliki rumah berarti memiliki tempat bermukim. Bisa dibayangkan jika kehilangan rumah. Menjadi gelandangan, numpang, dan sewa rumah adalah pilihan utama. Pendidikan adalah kunci untuk menjadi sejahtera. Pendidikan yang dienyam oleh warga menjadi ukuran kesejahteraan. Terbukti bahwa kebanyakan warga Indonesia tidak bisa mengenyam perguruan tinggi. Mayoritas masyarakat mandek di Sekolah Menengah Atas (SMA). Kesejahteraan tidak bisa dilihat sebagai angka dan data semata. Namun, secara riil mesti diamati. Kenyataannya, kesenjangan yang terjadi antara si kaya dan si miskin benar ekstrem.

Masyarakat telah mengartikan sifat dalam kesejahteraan masyarakat sangat kualitatif, yakni ada jaminan kemanan untuk mengamankan harta tapi mereka sehingga hidupnya tenang, akan tetapi negara justru sebaliknya, yakni pertambahan ternak sapi mereka yang diperoleh secara kredit sebagai indikasi semakin sejahtera hidup mereka. Sejahtera ditangkap sebagaimana memahami kemiskinan, yang diartikan karena ketidakmampuan untuk memenuhi kebutuhan. Pertanyaannya, apakah ketidaksejahteraan masyarakat itu identik dengan kemiskinan? Kelihatannya ada asumsi menyamakan keduanya, meskipun kemiskinan itu dapat merupakan salah satu indikasi ketidaksejahteraan. Akhir dari semua jawaban ini adalah peningkatan pendapatan perkapita, meskipun indikasi mutakhir tidak hanya dilihat pendapatan perkapita, melainkan juga terpenuhinya kebutuhan hidup minimum seperti kemampuan mengakses fasilitas kesehatan, pendidikan dan pemenuhan nutrisi.

Adapun upaya pemerintahan kelurahan dalam rangka memenuhi dan meningkatkan tingkat kepuasan masyarakat terhadap layanan yang diberikan adalah dengan memperbaiki sarana-sarana pelayanan yang dibutuhkan masyarakat. Perbaikan layanan kantor kelurahan mencakup sarana fisik yang langsung berhubungan dengan fasilitas pendukung layanan sebagai tempat atau lokasi 
waktu melayani kebutuhan masyarakat, maupun dengan mengadakan pelatihan-pelatihan bagi pegawai kelurahan dalam rangka meningkatkan kualitas sumberdaya manusia baik peningkatan kemampuan secara kepribadian/ psikologis yang biasa berhadapan langsung dengan masyarakat maupun keahlian yang bersifat teknis yang dapat mendukung mendukung terhadap kelancaran proses pelayanan. Kantor Kelurahan sebagai suatu unit fungsional yang berfungsi sebagai pusat pembangun publik, pusat pembinaan peran serta masyarakat dalam bidang publik serta pusat pelayanan kebutuhan tingkat pertama, memiliki tujuan dan cita-cita yang sangat besar. Meningkatkan kesejahteraan masyarakat dibutuhkan peran pemerintah yang bekerja untuk perbaikan kehidupan masyarakat sehingga dapat mengoptimalkan semua sumbar daya yang ada guna mencapai tujuan yang diinginkan sesuai visi dan misi pembangunan Pelayanan Publik.

Kelurahan Mataallo sebagai salah satu unit pelayanan publik yang terdepan juga harus memiliki pemimpin yang berorientasi pada suatu tujuan yang ingin dicapai. Kelurahan Mataallo dengan jumlah pegawai (staf) sebanyak 7 orang yang terdiri dari Pegawai Kelurahan Pegawai Negeri sipil (PNS) 4 orang, Pegawai Tidak Tetap (PTT) 3 orang. sangatlah tidak mudah untuk mengakomodir semua keinginan-keinginan masyarakat, untuk itulah peran pemerintah harus benar-benar dibutuhkan, sehingga kerjasama dan partisipasi aktif dari masyarakat guna mencapai visi dan misi serta tujuannya ingin dicapai oleh Kelurahan Mataallo.

Penulis tertarik meneliti terhadap persoalan di atas dengan harapan hasil penelitian dapat memberikan hasil dan berguna bagi di Kelurahan Mataallo Kecamatan Bajeng Kabupaten Gowa.

Penulis tertarik meneliti terhadap persoalan di atas dengan harapan hasil penelitian dapat memberikan hasil dan berguna bagi Kabupaten Maluku Utara.

\section{B. KERANGKA TEORIS}

Peran merupakan suatu perilaku yang penting bagi struktur sosial (Soekamto,
1983:146). Sedangkan menurut Biddle dan Thomas, mendefinisikan peran sebagai: "Serangkaian rumusan yang membatasi perilaku-perilaku yang diharapkan dari pemegang kedudukan tertentu (Sarwono, 1991: 243) "Ada pula yang mendefinisikan peran sebagai berikut : "Peran adalah sesuatu yang menjadi bagian atau yang memegang pimpinan yang terutama terjadi dalam suatu hal atau peristiwa (Purwanto,1994)" Melihat dari definisi diatas, dapat dikatakan bahwa peran yang dijalankan oleh seorang individu ataupun kelompok merupakan suatu cermin dari sebuah harapan dan tujuan yang akan dicapai terhadap perubahan perilaku yang menyertainya. Berhubungan dengan program promosi kesehatan yang dijalankan pemerintah adalah sebuah program yang meningkatkan kesadaran masyarakat tentang pentingnya berperilaku hidup bersih dan sehat (PHBS) sebagai hal paling utama dalam menjaga kesehatan diri dan lingkungan. Akan tetapi program promosi PHBS ini tidak akan berjalan jika tidak adanya peranan dari tokoh masyarakat ataupun kelompok yang ada di dalamnya. Peranan merupakan suatu konsep mengenai hal ikhwal yang dilakukan oleh individu dan masyarakat sebagai suatu rangkaian organisasi.

Peran juga dapat dilihat dari partisipasi seseorang atau organisasi terhadap lingkungan sosial dimana ia berada. Dalam teori partisipasi menurut Ndraha, "Partisipasi adalah merupakan keikutsertaan seseorang atau organisasi dalam berbagai hal secara tanggung jawab denga penuh kemurnian dan inisiatif dalam kegiatan kelompok yang dilaksanakan dalam mencapai tujuan" (dalam Ndraha, 1987: 10). Seseorang yang beradadi dalam masyarakat adalah individu ataupun kelompok yang mempunyai peran penting dalam keberhasilan program promosi PHBS. Karena mereka selain berfungsi sebagai komunikasi dan edukasi juga merupakan sumber informasi bagi khalayak masyarakat.

Kesejahteraan sosial adalah sistem yang terorganisasi dari pelayanan-pelayanan sosial dan institusi-institusi yang dirancang untuk membantu individu-individu dan kelompokkelompok guna mencapai standar hidup dan kesehatan yang memadai dan relasi-relasi per- 
sonal dan sosial sehingga memungkinkan mereka dapat mengembangkan kemampuan dan kesejahteraan sepenuhnya selaras dengan kebutuhan-kebutuhan keluarga dan masyarakatnya.

Kesejahteraan sosial sebagai suatu keadaan yang dirumuskan pada Pasal 2 ayat 1 Undang-Undang Nomor 6 tahun 1974 tentang ketentuan-ketentuan Pokok Kesejahteraan Sosial yaitu : Kesejahteraan sosial ialah suatu tata kehidupan dan penghidupan sosial materiil maupun spiritual yang diliputi oleh rasa keselamatan, kesusilaan dan ketentraman lahir batin, yang memungkinkan bagi setiap warga Negara untuk mengadakan usaha pemenuhan kebutuhan-kebutuhan jasmaniah, rohaniah dan sosial yang sebaik-baiknya bagi diri, keluarga serta masyarakat dengan menjunjung tinggi hak-hak asasi serta kewajiban manusia sesuai dengan Pancasila.

Todaro (2003) mengemukakan bahwa kesejahteraan masyarakat menengah kebawah dapat dipresentasikan dari tingkat hidup masyarakat. Tingkat hidup masyarakat ditandai dengan terentaskannya dari kemiskinan, tingkat kesehatan yang lebih baik, perolehan tingkat pendidikan yang lebih tinggi, dan tingkat produktivitas masyarakat. Dalam memahami realitas tingkat kesejahteraan, pada dasarnya terdapat beberapa faktor yang menyebabkan terjadinya kesenjangan tingkat kesejahteraan antara lain : 1). Social kegiatan ekonomi sektoral yang menjadi dasar kegiatan produksi rumah tangga atau masyarakat.2). Struktur kegiatan ekonomi sektoral yang menjadi dasar kegiatan produksi rumah tangga atau masyarakat dan 3). Potensi regional (sumberdaya alam, lingkungan dan infrastruktur) yang mempengaruhi perkembangan struktur kegiatan produksi, dan Kondisi kelembagaan yang membentuk jaringan kerja produksi dan pemasaran pada skala lokal, regional dan global (Taslim, 2004).

Kesejahteraan sosial mempunyai tujuan yaitu Untuk mencapai kehidupan yang sejahtera dalam arti tercapainya standar kehidupan pokok seperti sandang, perumahan, pangan, pangan, kesehatan, dan relasi-relasi sosial yang harmonis dengan lingkungannya dan Untuk mencapai penyesuian diri yang baik khusus- nya dengan masyarakat dilingkungannya, misalnya dengan menggali sumber-sumber, meningkatkan, dan mengembangkan taraf hidup yang memuaskan. Selain itu, Schneiderman (1972) mengemukakan tiga tujuan utama dalam sistem kesejahteraan sosial yang sampai tingkat tertentu tercermin dalam semua program kesejahteraan sosial, yaitu pemeliharaan sistem, pengawasan sistem, dan perubahan sistem.

Fungsi-fungsi kesejahteraan sosial bertujuan untuk menghilangkan atau mengurangi tekanan-tekanan yang diakibatkan terjadinya perubahan-perubahan sosio-ekonomi, menghindarkan terjadinya konsekuensi-konsekuensi sosial yang negatif akibat pembangunan serta menciptakan kondisi-kondisi yang mampu mendorong peningkatan kesejahteraan masyarakat (Friedlander \& Apte, 1982). Fungsi-fungsi kesejahteraan sosial tersebut antara lain : Fungsi pencegahan (Preventive), Fungsi penyembuhan (Curative), Fungsi Pengembangan (Development) dan Fungsi Penunjang (Supportive)

Untuk mencapai tujuan-tujuan kesejahteraan telah berkembang sebagai hasil dari perubahan-perubahan yang terjadi dalam kurun waktu sejarah yang berbeda-berbeda dan dipenngaruhi berbagai konsep yang berhubungan dengan tanggung jawab kemasyarakatan ataupun politis. Banyak Negara pada awalnya mendasarkan kesejahteraan sosial pada konsep residual yang ditandai oleh setiap program-program tambal sulam. Landasannya adalah asumsi yang menyatakan bahwa kewajiban sosial hanya diarahkan untuk memenuhi kebutuhankebutuhan darurat dari sebagian rakyat dianggap tidak mampu untuk memenuhi kebutuhan-kebutuhan sendiri melalui saranasarana tradisional dari pasar dan keluarga. kesejahteraan sosial menjalankan fungsi garis depan dari suatu masyarakat industri yang modern dengan tujuan untuk (1) menjamin stabilitas ekonomi dan politik, (2) menyediakan sumber-sumber penunjang utama bagi warga Negara, (3) memeratakan kesempatan, (4) memeratakan penghasilan dan kekuasaan. Pandangan ini merupakan bagian dari upaya untuk menemukan dan memberikan bagian 
yang sama kepada semua warga Negara sehubungan dengan hak-hak dan kewajibankewajiban terhadap masyarakatnya. Adanya konflik diantara ketidaksamaan antar golongan dan persamaan kewarganegaraan merupakan suatu faktor utama yang mendorong terjadinya demokratisasi amal dan terciptanya pandangan yang lebih positif tentang kesejahteraan sosial.

\section{METODE PENELITIAN}

Penelitian ini dilaksanakan di Kantor Kelurahan Mataallo Kecamatan Bajeng Kabupaten Gowa yang terletak di JL. Poros Limbung, Desa Jatia. Yang dimana lokasi ini menjadi objek penelitian kami mengingat peran pemerintah dalam peningkatan kesejahteraan masyarakat di kelurahan mataallo menjadi keinginan terbesar masyarakat kelurahan mataallo dan ingin diketaui bagaimana peran pemerintah di kelurahan mataallo dalam memberdayakan masyarkatnya. Jenis Penelitian ini adalah penelitian deskriptif kualitatif yakni suatu bentuk penelitian yang bertujuan untuk memberikan gambaran umun berbagai macam data yang di kumpulkan dari lapangan secara objektif berkaitan dengan objek penelitian tentang peran pemerintah kelurahan untuk peningkatan kesejahteraan masyarakat. Tipe penelitian ini adalah peneltitian secara survey, yakni suatu bentuk penelitian dalam pengumpulan data dengan melihat dan mendatangi langsung objek penelitian.

Penelitian ini menggunakan informan dengan sampel informan yaitu : lurah, Staf Kelurahan, Kepala Lingkungan dan Tokoh Masyarakat. Teknik Pengumpulan Data menggunakanTeknik Observasi dan Teknik wawancara. Jenis data penelitian ini adalah deskriptif kualitatif yaitu data berupa laporan yang berbentuk kata, kalimat, skema, dan gambar yang dijadikan dasar dalam memecahkan permasalahan yang ada. Data yang di peroleh dengan di analisis sedangkan penyajian data dalam bentuk narasi. Proses analisis data di mulai dengan menelaah seluruh data yang tersedia dari hsil wawancara mendalam, pengamatan (observasi) dan catatan lapangan dan Mereduksi data dengan cara membuat rangkuman (inti dan proses pernyataan dari informasi).

\section{HASIL PENELITIAN DAN PEMBAHASAN}

\section{Peran Pemerintah Dalam Peningkatan Kesejahteraan Masyarakat di Kelurahan Mataallo Kecamatan Bajeng Kabupaten Gowa.}

Kesejahteraan ialah suatu tata kehidupan dan penghidupan sosial, materil ataupun spiritual yang diiputi oleh rasa keselamatan, kesusialaan, dan ketentraman lahir batin, yang memungkinkan bagi setiap warga Negara untuk mengadakan usaha pemenuhan kebutuhan-kebutuhan jasmaniah, rohaniah, dan sosial dan sebaik-baiknya bagi diri, keluarga serta masyarakat dengan menjunjung tinggi hak-hak asasi serta kewajiban manusia sesuai dengan pancasila.

Kesejahteraan merupakan hal yang diinginkan semua orang, dimana tercapai dan terpenuhinya kebutuhan-kebutuhan masyarakat dalam kehidupan sosial. Oleh karena itu salah satu cara yang dilakukan dalam meningkatkan kesejahteraan masyarakat adalah memaksimalkan tanggung jawab dari pemerintah kelurahan dimana peran dan fungsinya merupakan hal yang penting dilakukan, diamana peranan itu berbentuk dalam sebuah program-program pemerintah di kelurahan dalam menunjang peningkatan kesejahteraan masyarakat.

Pentingnya peran pemerintah kelurahan mataallo kecamatan bajeng kabupaten gowa, maka perlu dilakukan penilaian mengenai pelaksanaan peran yang selama ini dilakukan. Hal ini bertujuan untuk menilai apakah pelaksanaan pengawasan yang telah dilakukan telah sesuai dengan yang diharapkan. Oleh karena itulah maka penilaian peran pemerintah pada kelurahan mataallo kecamatan Bajeng kabupaten Gowa ditekankan pada pelaksanaan kegiatan pemerintahan kelurahan, pelaksanaan kegiatan ekonomi dan pembangunan, pelaksanaan kegiatan pemberdayaan masyarakat dan kesejahteraan rakyat, penyelenggaraan ketentraman dan ketertiban umum, dan pelaksanaan Kegiatan ketata-usahaan. 


\section{Pelaksanaan Kegiatan Pemerintahan Kelurahan Mataallo Kecamatan Bajeng Kabupaten Gowa}

Dalam melaksanakan peran oleh pemerintah kelurahan mataallo kecamatan bajeng kabupaten gowa, sebagai pelaksana kegiatan pemerintah kelurahan. Alasan dilakukan pelaksanaan kegiatan pemerintah kelurahan adalah untuk menilai apakah pemerintah kelurahan telah melaksanakan kegiatan pemerintah dan tidak ada penyimpangan dalam pelaksanaan kegiatan pemerintah kelurahan, dan selain itu dapat dilakukan tindakan perbaikan dalam pelaksanaan kegiatan pemerintahan khususnya di kelurahan mataallo. Penilaian dalam melakukan kegiatan pemerintah kelurahan khususnya pada Kelurahan Mataallo Kecamatan Bajeng Kabupaten Gowa, sesuai dengan hasil wawancara dengan bapak kepala yaitu sebagai berikut :

"Pelaksanaan kegiatan pemerintah kelurahan selama ini belum berjalan dengan baik, karena masih banyak kebutuhan masyarakat yang belum terpenuhi di wilayah kelurahan ini" (Wawancara SH, 21 Januari 2013)

Berdasarkan hasil wawancara yang sebagaimana telah dilakukan dengan beliau dapat disimpulkan bahwa dalam pelaksanaan kegiatan pemerintah kelurahan belum efektif, penyebab dari kurang efektifnya pelaksanaan kegiatan pemerintah kelurahan ini ialah dimana kebutuhan-kebutuhan masyarakat belum terpenuhi, persoalan ini membuat permasalahan-permasalahan terus terjadi seperti masih banyaknya keluhan dari masyarakat tentang pembagian beras miskin (Raskin), dimana masih banyak masyarakat yang tidak dapat beras raskin dikarenakan. Padahal pembagian raskin merupakan program pemerintah dalam upaya pelayanan kepada masyarakat dalam membantu masyarakat memenuhi kebutuhan sehari-harinya dan program raskin ini harus dibagi secara merata kepada masyarakat miskin.

Kemudian wawancara dengan masyrakat setempat ;
"Untuk memenuhi kebutuhan masyarakat di kelurahan mataallo tidak mudah, butuh waktu panjang. Pemerintah harus lebih peka terhadap masalah sosial. Jadi pemerintah harus memperbanyak kegiatan dan program kelurahan dalam menunjang kehidupan masyarakat." (wawancara DNG 21 Februari 2013)

Dari hasil wawancara yang sebagaimana telah dilakukan dengan beliau dapat disimpulkan bahwa untuk memenuhi kebutuhan masyarakat pemerintah kelurahan mataallo dituntut untuk lebih peka terhadap masalah sosial, dan pemerintah kelurahan mataallo diharapkan dapat melaksanakan dan membuat program-program kelurahan dalam meningkatkan partisipasi masyarakat dalam upaya menunjang kehidupan masyarakat dalam upaya peningkatan kesejahteraan. Program yang selama ini pemerintah kelurahan matallo selama ini belum maksimal, diantaranya pembagian raski, perbaikan jalan, dan membangun drainase. Pemerintah seharusnya memfasilitasi masyarakat dalam menyediakan modal dalam pengembangan usaha kecil masyarakat. Dengan itu masyarakat mampu menjalankan usaha tersebut secara aktif dalam upaya meningkatkan taraf hidup masyarakat. Di kelurahan mataallo ada beberapa masyarakat yang berprofesi sebagai pengusaha rumput laut, tukang kayu, tukang ojek, dan pengendara ojek bentor yang dilakukan masyarakat dalam melangsungkan kehidupannya, sehingga hal inilah yang harus diperhatikan oleh pemerintah kelurahan dalam menyelenggarakan roda pemerintahan dalam upaya meningkatkan kesejahteraan, ekonomi dan sosial masyarakat.

\section{Kegiatan Ekonomi dan Pembangunan}

Berdasarkan hasil penilaian mengenai peran pemerintah kelurahan mataallo maka selanjutnya adalah dalam kegiatan ekonomi dan pembangunan yang dijalankan oleh pemerintah kelurahan Mataallo kecamatan Bajeng kabupaten Gowa.

Dalam uraian tersebut diatas, maka di sajikan hasil wawancara dengan mengemukakan bahwa : 
"Pelaksanaan kegiatan ekonomi di kelurahan mataallo cukup aktif, diantaranya adanya PNPM Mandiri dimana masyarakat diberikan modal usaha kecil dalam bentuk kelompok, kredit KUR di BRI, dan untuk usaha tani dengan bentuk gabungan kelompok tani untuk usaha dibidang pertanian. Hal ini diupayakan untuk memperlancar sarana produksi pertanian, seperti pupuk racun dan bibit agar usha petani meningkat". (Wawancara DS, 21 Februari 2013)

Berdasarkan hasil wawancara yang telah dikemukakan di atas, maka dalam pelaksanaan kegiatan ekonomi dan pembangunan di kelurahan Mataallo sudah berjalan sebagaimana yang telah diuraiakn oleh informan diatas. Pemerintah berperan dalam kegiatan tersebut dalam upaya meningkatkan taraf ekonomi masyarakat, seperti PNPM Mandiri, Kredit Usaha Rakyat (KUR) yang dimana hal itu merupakan upaya pemerintah melakukan hal tersebut dalam pelayanan dan menyelenggarakan peran dan fungsinya sebagai pelayan masyarakat itulah yang menjadi tanggung jawab pemerintah yang terealisasikan melalui program-program dan kegiatan-kegiatan kelurahan. Oleh karena itu pemerintah diharapkan dapat memaksimalkan program-program pemerintah kelurahan dalam kegiatan ekonomi. Oleh karena itu pemerintah diharapkan dapat memaksimalkan program-program pemerintah kelurahan dalam kegiatan ekonomi dan pembangunan masyarakat sehingga dalam upaya meningkatkan taraf kehidupan ekonomi masyarakat dapat tercapai.

Kemudian wawancara dengan salah seorang informan mengatakan bahwa :

"Pelaksanaan kegiatan ekonomi dan pembangunan berjalan tidak maksimal, masih banyak desa yang belum disentuh oleh pemerintah sehingga tidak merata ke semua wilayah kelurahan". (Wawancara SN, 22 Februari 2013)

Dari hasil wawancara yang sebagaimana yang telah dilakukan ternyata dalam pelaksanaan kegiatan ekonomi dan pembangunan di Keurahan Mata Allo, tidak maksimal. Dimana kegiatan-kegiatan ekonomi dan pembangunan hanya dilakukan di beberapa desa dan tidak menyentuh semua desa karena dalam lingkup pemerintahan yang namanya pembangunan tentunya bertahapa dan tidak sekaligus semua, makanya diperlukan waktu yang cukup panjang untuk menyentuh semua desa. Sehingga diharapkan pemerintah mampu memaksimalkan kegiatan ekonomi dan pembangunan secara merata ke seluruh desa.

\section{Pemberdayaan Masyarakat}

Peran pemerintah kelurahan dalam pemberdayaan masyarakat merupakan hal yang penting bagi masyarakat. Sebagai kegiatan dalam memberdayakan dan meningkatkan sumber daya manusia yang ada di masyarakat kelurahan mataallo, sehingga pemberdayaan ini merupakan hal yang penting dalam kehidupan.

Kemudian dari hasil wawancara dengan bernama Tawang dapat diuraikan sebagai berikut :

"Pemberdayaan masyarakat sudah dilaksanakan, adapun dalam pelaksanaannya belum maksimal". (Wawancara, TW,22 Februari 2013)

Berdasarkan hasil wawancara dengan beliau maka kesimpulan yang dapat diambil bahwa pemberdayaan masyarakat di kelurahan Mata Allo sudah terlaksana namun belum maksimal. Belum maksimalnya pemberdayaan masyarakat dikarenakan di Kelurahan Mata Allo fasilitas dan infrastruktur belum memadai. Adapun pemberdayan masyarakat yang dilakukan pmerintah kelurahan diantaranya pelayanan pendidikan dan kesehatan gratis, penambahan gizi dan penimbangan bagi balita di pusat pembantu (PUSTU), pembinaan kegiatan pemuda desa seperti karang taruna dan sanggar seni dalam melaksanakan kegiatan di Kelurahan Mataallo Kecamatan Bajeng Kabupaten Gowa. Oleh karena itu pemerintah diharapkan dapat memaksimalkan pemberdayaan masyarakat dalam menunjang kehidupan masyarakat dalam kehidupan sehari-hari upaya dalam meningkatkan taraf hidup dapat tercapai.

\section{Pelayanan Masyarakat}


Fungsi pelayanan masyarakat merupakan hal yang paling penting dari tugas penyelenggara pemerintha dalam menjalankan roda organisasi pemerintahan.

Kemudian dari hasil wawancara dengan bapak "Daeng Bani" dapat diuraikan sebagai berikut :

"Masyarakat di kelurahan mataallo masih jauh dari yang namanya sejahtera. Karena rata-rata penduduk kelurahan mataallo adalah petani dan pedagang". (Wawancara DB 23 Februari 2013)

Berdasarkan hasil wawancara dengan beliau maka kesimpulan yang dapat diambil bahwa usaha dalam memberdayakan masyarakat di kelurahan mataallo belum tercapai, dominan masyarakat kelurahan mataallo masih belum termasuk kategori sejahtera. Masyarakat rata-rata hanya mencukupi untuk kebutuhannya sehari-hari, pemerintah diharapkan dapat membuka lapangan pekerjaan untuk masyarakat dalam meningkatkan taraf kehidupannya.

\section{Faktor Peningkatan Kesejahteraan Masyarakat di Kelurahan Mataallo Kecamatan Bajeng Kabupaten Gowa.}

\section{Faktor Internal}

Berdasarkan hasil wawancara yang telah peneliti lakukan kepada beberapa narasumber, maka diperoleh penjelasan tentang faktor-faktor peningkatan kesejahteraan masyarakat di Kelurahan Mata Allo Kecamatan Bajeng Kabupten Gowa :

\section{a. Tingkat Pendidikan}

Acuan peneliti dalam faktor internal tingkat kesejahetraan masyarakat adalah faktor yang berada di dalam masyarakat kelurahan mataallo kecamatan bajeng kabupaten gowa. Dimana faktor internal ini akan sangat membantu dalam peningkatan kesejahteraan masyarakat. Jadi kesejahteraan suatu masyarakat ditentukan dari sejauh mana kebutuhan masyarakat mampu terpenuhi.

Terkait faktor internal tingkat kesejahteraan masyarakat di Kelurahan Mata Allo :
"Tingkat pendidikan masyarakat di kelurahan Mataallo baik, karena karena cukup banyak masyarakat yang sudah bergelar akedemi atau sarjana". (Wawancara , yy 23 Februari 2013)

Dengan hasil wawancara diatas, dengan beliau maka dapat disimpulkan bahwa tingkat pendidikan masyarakat yang ada di Kelurahan Mataallo Kecamatan Bajeng Kabupaten Gowa bahwa masyarakat sudah banyak yang mengenyam pendidikan. Sehingga dalam upaya untuk meningkatkan kesejahteraan dapat tercapai. Tingkat pendidikan masyarakat sangat menentukan nasib dan harapan hidup masyarakat dalam kesehariannya. Karena peluang untuk mendapatkan pekerjaan dan posisi dimasyarakat juga ditentukan oleh tingkta pendidikan seseorang. Namun disamping banyaknya masyarakat yang sudah mengenyam pendidikan, akan tetapi masih banyak pula masyarakat yang tidak sempat mengenyam pendidikan di Kelurahan Mata Allo ini. Karena menurut peneliti pendidikan bagi masyarakat itu sangat penting, karena pendidikan dapat memberikan sumbangsih besar terhadap kehidupan, sehingga tingkat pendidikan ini penting dalam kehidupan masyarakat.

\section{b. Tingkat Pendapatan}

Pendapatan masyarakat juga menentukan tingkat kesejahteraan masyarakat. Sehingga pendapatan ini yang mejadi salah satu tolak ukur tingkat kesejahteraan masyarakat.

Terkait pendapatan masyarakat, salah seorang informan menjelaskan :

"Kalau mau dilihat-lihat masyarakat di kelurahan mataallo ini kebanyakan petani dan pedagang, jadi pendapatan sehari-harinya cukuplah untuk kebutuhan sehar-harinya". (Wawancara CY 24 Februari 2013)

Berdasarkan hasil wawancara di atas dapat dikemukakan bahwa, masyarakat di kelurahan mataallo memiliki pendapatan yang cukup memadai artinya cukup untuk kebutuhan sehari-hari, karena masyarakat kelurahan Mataallo lebih mendominasi yang berpenghasilan sebai petani dan pedagang. Sekalipun ada juga masyarakat yang berprofesi sebagai 
PNS akan tetapi tingkat pendapatan tidak mempengaruhi secara signifikan tingkat kesejahteraan masyarakat.

\section{c. Pekerjaan}

Mata pencaharian atau pekerjaan masyarakat sangat menentukan kesejahteraan. Dalam hal ini pekerjaan menjadi poin penting dalam indikator kesejahteraan masyarakat.

Terkait pekerjaan yang menjadi poin penting dalam kesejahteraan masyarakat, seperti yang disampaikan oleh salah seorang informan :

"Rata-rata pekerjaan masyarakat di kelurahan mataallo ini adalah petani dan pedagang yang menjadi aktivitas sehari-hari nya". (Wawancara, SJ 25 Februari 2013)

Dengan melihat yang pekerjaan masyarakat di Kelurahan Mataallo Kecamatan Bajeng, dapat disimpulkan bahwa masyarakat dominasi pekerjaan adalah petani dan pedagang, namun di Kelurahan Mataallo ini beragam pekerjaan masyarakat seperti, PNS (Guru, TNI, POLRI) buruh harian, tukang kayu, tukang ojek dan ibu rumah tanggga. Namun pekerjaan masyarakt belum mampu mempengaruhi tingkat kesejahteraan masyarakat.

\section{Faktor Eksternal}

Berdasarkan hasil wawancara yang telah peneliti lakukan kepada beberapa narasumber, maka diperoleh penjelasan tentang faktor-faktor peningkatan kesejahteraan masyarakat di Kelurahan Mata Allo Kecamatan Bajeng Kabupten Gowa :

\section{a. Kemudahan akses finasial pada lembaga keuangan}

Pada dasarnya masyarakat mempunyai hak untuk mengakses finansial (uang) pada lembaga keuangan (Bank dan lain-lain). Sehingga masyarakat aktif dan berperan dalam membantu pemerintah dalam menjalankan kegiatan ekonomi dan pembagunan di-masyarakat.

Terkait kemudahan akses finansial pada lembaga keuangan di Kelurahan Mata Allo Kecamatan Bajeng Kabupaten Gowa, infrorman menjelaskan :

"Untuk mengakses financial pada lembaga keuanggan selama ini berjalan dengan baik, masyarakat bisa dengan mudah mengakses uang melalui lembagaa keuangan tersebut". (Wawancara,SYM 7 Februari 2013).

Dengan hasil wawancara diatas, peneliti dapat menyimpulkan bahwa di Kelurahan Mataallo Kecamatan Bajeng Kabupaten Gowa bahwa masyarakat dengan mudah mengakses finasial melalui lembaga keuangan. Masyarakat bisa mengambil uang di lembaga keuangan seperti Bank, koperasi, dan lembaga sosial kemasyarakatan lainnya untuk dipinjam sebagai modal awal dalam membangun usaha. Seperti yang ada di kelurahan Mataallo diantaranya, PNPM Mandiri dan Kredit Usaha Rakyat (KUR). Diamana kedua hal ini dapat dengan mudah diakses masyarakat apabila menginginkan hal tersebut. Hal ini merupakan upaya pemerintah dan masyarakat dalam pengembangan usaha sehingga kesejahteraan masyarakat tercapai.

\section{b. Akses Bantuan Pemerintah}

Peran pemerintah sangat di butuhkan dalam memfasilitasi masyarakat dalam pengembangan usaha masyarakat dalam meningkatkan kesejahteraan. Pemerintah di harapkan dapat menyediakan akses dan bantuan kepada masyarakat dalam upaya peninggkatan kesejahteraan.

Dalam memberikan akses dan bantuan pemerintah kepada masyarakat di kelurahan, informan menjelaskan :

"Bantuan Pemerintah kelurahan selama ini sudah berjalan dengan baik, namum hal ini belum maksimal". (Hasil Wawancara, AD 1 Februari 2013)

Berdasarkan hasil wawancara tersebut, peneliti berkesimpulan bahwa dalam memberikan akses dan bantuan pemerintah di Kelurahan Mata Allo Kecamatan Bajeng Kabupaten Gowa sudah berjalan dan terlaksana. Namun dalam pelaksanaan itu belum maksimal. Pemerintah Kelurahan Mataallo telah melaksanakan program dalam upaya membantu masyarakat seperti, pembagian sembako, memberikan alat-alat tani seperti pupuk dan racun padi, dimana hal itu dilakukan untuk membantu masyarakat dalam memaksimalkan usaha dan kerja keras masyarakat dalam meningkatkan taraf hidupnya sehingga kesejahteraan tercapai. 


\section{E. KESIMPULAN}

Peran pemerintah kelurahan dilihat dari penyelenggara kegiatan pemerintah kelurahan, pemberdayaan masyarakat, dan pelayanan masyarakat belum maksimal, seperti kegiatan dan program pemerintah kelurahan tidak berjalan secara maksimal, belum maksimalnya pemberdayaan masyarakat dan peningkatan kesejahteraan masyarakat di Kelurahan Mata Allo Kecamatan Bajeng Kabupaten Gowa.

Faktor yang mempengaruhi peningkatan kesejahteraan masyarakat di Kelurahan Mata Allo Kecamatan Bajeng Kabupaten Gowa. Antara lain faktor internal dan faktor eksternal. Faktor internal seperti (a) pendapatan, (b) pendidikan, dan (c) pekerjaan, sedangkan faktor eksternal seperti (a) kemudahan akses finansial pada lembaga keuangan, dan (b) akses bantuan pemerintah.

\section{DAFTAR PUSTAKA}

Albrow Martin, 1989. Birokrasi, Yogyakarta : PT.Tiara Wacana

Fahrudin Adi, 2012, Pengantar Kesejahteraan Sosial, Bandung: Penerbit Refika Aditama,

Hakim Lukman, 2011, Filosofi Kewenangan Organ Lembaga Daerah, Malang : Penerbit: Setara Press,

Haryatmoko, 2011. Etika Publik Untuk Integritas Pejabat Publik dan Politisi, Jakarta : PT Gramedia Pustaka Utama,

Mas'oed Mohtar, 1994 Politik, Birokrasi dan Pembangunan, Yogyakarta: Pustaka Pelajar

Nurdjaman Progo, 2004. Pokok-Pokok Penyelenggaraan Pemerintahan Umum, Direktur Jenderal Pemerintahan Umum, Depdagri.
Sinambela Lijan Poltak, dkk 2010. Reformasi Pela-yanan Publik, Jakarta : Penerbit Bumi aksara,

Sudirwo Daeng. 1981. Pokok-Pokok Pemerintahan Di Daerah dan Pemerintahan Desa, Bandung : Penerbit Angkas

Syarifin Pipin, dkk, 2011 Pemerintah Daerah Indonesia,Bandung: PenerbitPustakaSetia,

http://translate.google.co.id/translate?hl=id\& langpair =en $\mid \mathrm{id} \& u=h t t p: / / w w w$. eldtrain.com.au/members/library/ sml03.htm Di Akses 10 oktober 2011

http://community.siutao.com/showthread. php/1684-Lea dership -TeoriKepemimpinan"http://community. siutao.com/showthread.php/1684Leadership-Teori-Kepemimpinan Di Akses 10 oktober 2011

http://www.scribd.com/doc/15885060/TeoriKepemimpinan Di Akses 10 oktober 2011

http://www.UNISOSDEM.ORG/Investasi dan Peran Pemerintah/Henry F Noor. Di akses 12 oktober 2012

http://www.bigs.or.id/peneliti di bandung Institute Of Governance Studies/good governance dan kesejahteraan/Andriyansyah/ Di akses 29 november 2012

http//:www.pertahanannasional.com/Peran Pemerintah dalam Ekonomi/ Entrepreneur Muda Indonesia/Riskie Purnama Yulya dkk/Di akses 5 mei 2011

http://www.pajak.go.id. Nad_Nid_Nud's Blogs/My Civics Education's Blog/ nadyyaa/peranan pemerintah dalam ekonomi pembangunan/Di akses 20 november 2010. 